\title{
EFFECT OF SMALL MOLECULE INHIBITOR FISETIN OVER PROLIFERATION OF HUMAN NON-SMALL CELL PULMONARY CARCINOMA
}

\section{Gazala Showkat and Sreepriya M*}

Department of Microbiology and Biotechnology, Bangalore University, Jnana Bharathi Campus, Bangalore, India - 560056

Received - July 21, 2016; Revision - August 27, 2016; Accepted - September 24, 2016

Available Online - October 13, 2016

DOI: http://dx.doi.org/10.18006/2016.4(Spl-2-SSPN).S29.S38

\section{KEYWORDS}

Fisetin

Lung carcinoma

A549

NCI-H460

Apoptosis

Proliferation.

ABSTRACT

The percentage of cancer-related deaths attributable to diet and tobacco globally is reported to be as high as $60-70 \%$. A large number of dietary compounds have gained research interest and tested to determine their chemopreventive / antiproliferative effects on in-vivo/in-vitro models. The present study effect of flavonoid fisetin on proliferation of human lung carcinoma cells A549 and NCI-H460 was investigated. The effect of fisetin on cell growth was investigated by MTT, Crystal violet, XTT, LDH release, and colony forming assays. Cell proliferation was assessed by BrdU incorporation test. Further, cell morphology and cytopathology was analyzed by crystal violet test and hematoxylin and eosin staining. Results of study revealed that fisetin treatment exerted a dose dependent decrease in the growth of A549 and NCI-H460 cells with $\mathrm{IC}_{50}$ values of $190 \mu \mathrm{M}$ and $210 \mu \mathrm{M}$ respectively. It also inhibited cell proliferation and colony formation in both A549 and NCI-H460 cells. Cytopathology studies exhibited features such as nuclear fragmentation, cytoplasmic vacuolation, karyorrhexis, chromatin condensation, which were suggestive of apoptotic cell death. Results of the study indicate growth inhibitory, antiproliferative and pro-apoptotic effects of fisetin on lung carcinoma cells.
\end{abstract}

* Corresponding author

E-mail: mpriya7@yahoo.com(M. Sreepriya)

Peer review under responsibility of Journal of Experimental Biology and Agricultural Sciences.

Production and Hosting by Horizon Publisher India [HPI] (http://www.horizonpublisherindia.in/).

All rights reserved.
All the article published by Journal of Experimental Biology and Agricultural Sciences is licensed under a Creative Commons Attribution-NonCommercial 4.0 International License Based on a work at www.jebas.org.

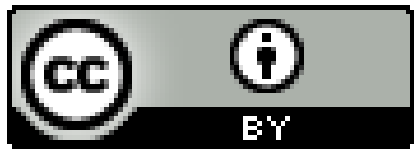




\section{Introduction}

Chemoprevention and functional foods are new areas of great interest in the prevention of diseases. Further, it has been reported that dietary and environmental factors account about $30 \%$ of cancers, suggesting that diet plays an important role in the prevention of cancer (Doll \& Peto, 1981). In the past two decades a large number of dietary compounds have been tested to determine their chemopreventive / anti proliferative activity in vivo/in vitro model systems. Flavonoids are naturally occurring polyphenolic compounds that have very low molecular weight and form a large group of secondary plant metabolites. These compounds have various interesting biological activities such as antioxidative, antimicrobial, anticarcinogenic and cardioprotective (Khan et al., 2008; Moon et al., 2006). Fisetin a major flavonoid has been reported to possess pharmacological properties like anticancer (Huntington et al., 2004), angiogenesis-inhibition (Hirata et al., 2003), antiinflammatory (Kemik et al., 2011), pro-apoptotic (Liu et al., 2012) and anti-invasive effects (Behrens et al., 2001). Thus fisetin could confer a valuable advantage in treatment of various types of cancers. Like many other flavonoids, fisetin (3, 3, 4, 7-tetrahydroxy flavone), is widely distributed among fruits and vegetables and is found in plants at a concentration of $160 \mu \mathrm{g} / \mathrm{g}$ (Arai et al., 2000).

Lung cancer is the second most common cancer and is the major cause of cancer related death in both men and women. Instead of great advancements in chemotherapy survival rates for lung cancer patients is still disappointing. Majority of the lung cancer patients are in stages III and IV when diagnosed making curative surgery difficult. Based on cell morphology pulmonary cancer is primarily categorized into Non Small Cell Lung Carcinoma (NSCLC) and Small Cell Lung Carcinoma (SCLC). NSCLC is further classified into adenocarcinoma, squamous cell lung carcinoma, and large cell lung carcinoma and comprises nearly 75 to $80 \%$ of all lung cancers. The mean 5 - year survival rate for those with NSCLC is approximately 15\% (Carbone \& Felip, 2011). Recent evidences strongly suggest abnormalities in JAK/STAT signaling pathway is involved in the oncogenesis of several cancers especially lung cancers (Song et al., 2011). STAT3 is persistently activated in about $50 \%$ of NSCLC primary tumors and lung cancer-derived cell lines (Mukohara et al.,2003; Seki et al.,2004; Haura et al., 2005). Constitutive activation of the P13K/Akt pathway has also been reported in $90 \%$ of NSCLC cell lines, thus promoting cell survival and resistance to chemotherapy or $\gamma$ radiation (West et al., 2003).

Exploiting and exploring actions of natural products on suitable model systems has led to development of several life saving drugs available in the market today to treat dreadful diseases. Hence, this study is an attempt to understand the anticancer properties of dietary flavonoid/small molecule inhibitor fisetin on suitable human NSCLC in vitro model systems.

\section{Materials and Methods}

\subsection{Chemicals}

Fisetin (3,3', 4',7-tetrahydroxyflavone) was procured from (sigma, St. Louis , MO, USA). A stock solution of $2.86 \mathrm{mg} / \mathrm{ml}$ of fisetin was prepared in DMSO and stored at $-20^{\circ} \mathrm{C}$.

\subsection{In-vitro model systems}

\subsubsection{Isolation and culture of lymphocytes}

Fresh blood was collected and lymphocytes were separated by following the previously described protocol (Boyum, 1968). Based on the density gradient centrifugation the lymphocyte separation carried out using separation media (Hisep ${ }^{\mathrm{TM}}-\mathrm{LSM}$ 1001) procured from Himedia, India. Lymphocytes were culture in complete DMEM media containing $10 \%$ FBS at $37^{\circ} \mathrm{C}$ with $5 \% \mathrm{CO}_{2}$ and $95 \%$ humidity in a $\mathrm{CO}_{2}$ incubator.

\subsubsection{Procurement and maintenance of cell lines}

The NSCLC pulmonary carcinoma cell lines A-549 (adenocarcinoma), NCI-H460 (large cell lung carcinoma) and normal lung fibroblast cells WI-26 were procured from National Centre for Cell Science (NCCS), Pune, India. The A-549, NCI-H460 and WI-26 cells were cultured in Hams F12K medium (AL106A- Himedia, India), RPMI 1640 (AL171A- HiMedia, India) and DMEM (AL007- Himedia India) respectively. The media were supplemented with $10 \%$ Fetal Bovine Serum (FBS, RM112, Himedia, India), 1X and Antibiotic and Antimycotic solution (A007, Himdia, India) for growth of cells, and cells were grown under standard growth conditions ( $95 \%$ humidity, $5 \% \mathrm{CO} 2$ and temperature $37{ }^{\circ} \mathrm{C}$ ) in a $\mathrm{CO}_{2}$ incubator.

\subsection{Cell proliferation and cytotoxicity assays:}

\subsubsection{MTT assay}

Cells were seeded at $1 \times 10^{4}$ cells / well of 96- well micro titer plates and cultured overnight and treated with fisetin in the dose range of $10 \mu \mathrm{M}$ to $400 \mu \mathrm{M}$ concentration and were allowed to proliferate $24 / 48 \mathrm{~h}$ (temperature $37^{\circ} \mathrm{C}, 5 \% \mathrm{CO}_{2}$ and 95\% humidity). After proliferation, MTT performed following the previously described protocol (Mosmann, 1983). Plates was read at $570 \mathrm{~nm}$ using a microplate reader and the concentration of fisetin that inhibited cell growth by $50 \%$ $\left(\mathrm{IC}_{50}\right)$ was calculated.

\subsubsection{XTT assay}

XTT (2,3-Bis-(2-Methoxy-4-Nitro-5-Sulfophenyl)-2HTetrazolium-5-Carboxanilide) assay was performed using a commercially available kit (HiMedia, Cat. No. CCK015) 
following the manufacturer's recommendations. Cells after treatment were allowed to proliferate (temperature $37^{\circ} \mathrm{C}, 5 \%$ $\mathrm{CO}_{2}$ and $95 \%$ humidity). Activated XTT solution was added to the wells and cells were incubated for 2 to 4 hours and the absorbance was read at $450 \mathrm{~nm}$ using ELISA reader.

\subsubsection{Bromodeoxyuridine (BrdU) assay}

Cell proliferation was measured by performing BrdU (5bromo-2'-deoxyuridine) incorporation assay using commercially available kit (Calbiochem/Merck, Cat. No. QIA58, Whitehouse Station, NJ, USA) following the manufacturer's guidelines. The absorbance was recorded at $450 \mathrm{~nm}$ and measured intensity is proportional to the amount of incorporated BrdU in the cells.

\subsubsection{Crystal violet assay}

Crystal violet assay was performed to determine the effect of fisetin on cell viability following the protocol previously described (Lena et al.,2009). The treated and untreated control cells were stained with crystal violet $(0.05 \% \mathrm{w} / \mathrm{v})$ for $30 \mathrm{~min}$ after that wells were thoroughly washed with distilled water and destained with sorenson's buffer. The absorbance of the extracted stain was measured at $540 \mathrm{~nm}$.

2.4 Assays to determine change in cell morphology and apoptotic cell death

\subsubsection{Crystal violet staining}

Light microscopy analysis of treated and untreated control cells was carried out by fixing the cells in $10 \%$ formalin saline and subsequent staining with $0.05 \mathrm{w} / \mathrm{v}$ crystal violet for 30 minutes. Cells were observed under phase contrast microscope and images were captured $(4 \times 10 \mathrm{X}$ magnification).

\subsubsection{Hematoxylin and Eosin staining}

Cells after treatment were fixed in $10 \%$ formalin and the morphology change in both were analysed by staining the cells with hematoxylin and eosin following the protocol previously described (Fischer et al., 2008). Cells were observed under light microscope and images were captured $(4 \times 10 \quad \mathrm{X}$ magnification).

\subsection{Soft agar assay for colony formation}

A cell suspension $\left(5 \times 10^{3}\right.$ cells/well $)$ in $1 \mathrm{ml}$ of $0.3 \%$ agar with complete media was over laid on $35 \mathrm{~mm}$ dish containing $0.5 \%$ base agar as described previously (Hamburger et al., 1978). The media was changed two times a week and cells were maintained under standard growth conditions (temperature $37^{\circ} \mathrm{C}, 5 \% \mathrm{CO}_{2}$ and $95 \%$ humidity) in a $\mathrm{CO}_{2}$ incubator (Forma Scientific, USA). After 15 days, the colonies formed in the untreated control and the treated groups were fixed with $3.7 \%$ paraformaldehyde and stained with crystal violet $(0.05 \%)$ for 1 hour. The colonies were counted under light microscope and images were captured (magnification $10 \mathrm{X}$ ).

\subsection{LDH cytotoxicity assay}

The release of lactate dehydrogenase from treated and untreated control cells was performed by using LDH cytotoxicity colorimetric Assay kit 11(catalog no.K313-500) as per the manufacturer's recommendations. After the treatment of cells, the clear medium ( $10 \mu \mathrm{l} /$ well) from treated, control and high control groups was transferred into a clear 96-well plate.

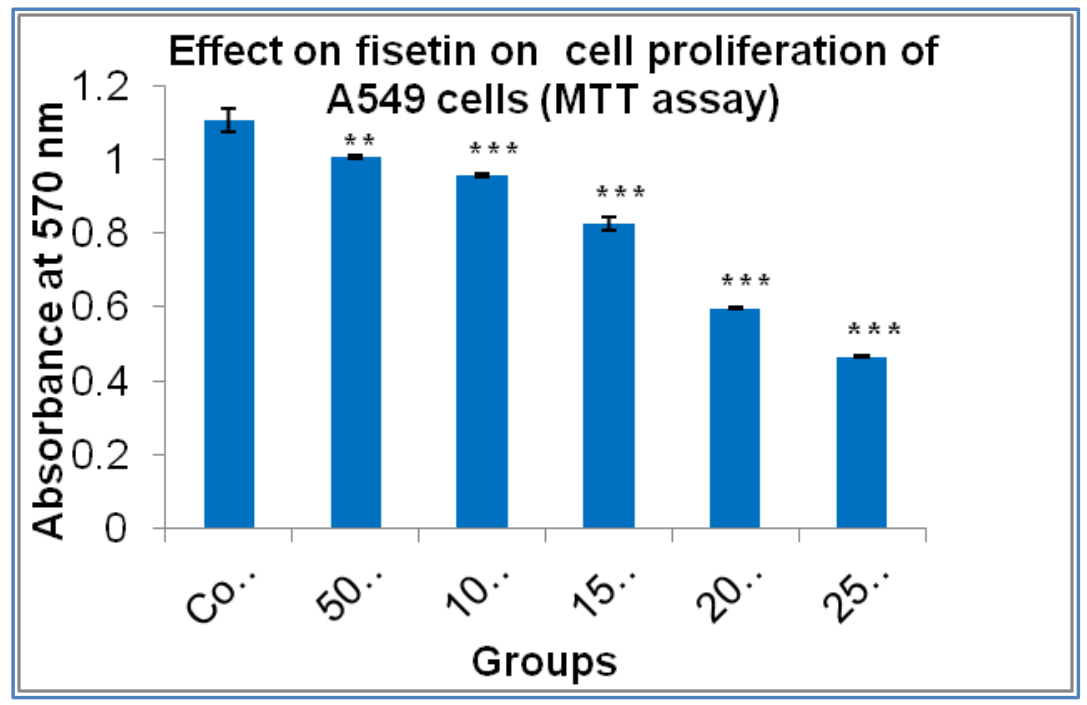

Figure 1(a). Effect of fisetin on proliferation of A549 cells (MTT assay) - pilot studies. Treatment of A549 cells with $50 \mu \mathrm{M}-250 \mu \mathrm{M}$ concentration showed statistically significant $(\mathrm{p}<0.001)$ decrease in the proliferation of A549 cells. Data represents mean \pm SD of six replicates. Intergroup comparisons were made between the cell control and the treated groups. Student's t-test; ***P $<<0.001,{ }^{*} \mathrm{P}<0.01$, verses control. 


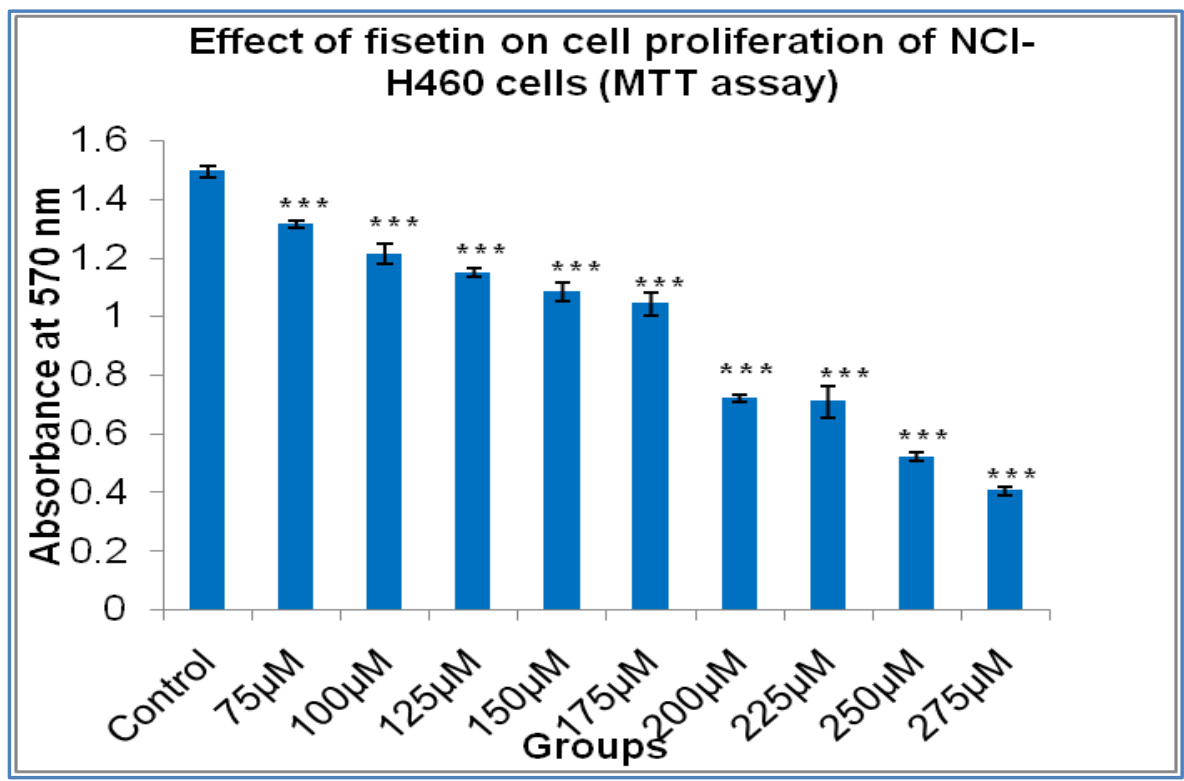

Figure 1(b) Effect of fisetin on proliferation of NCI-H460 cells (MTT assay) - pilot studies. Treatment of NCI-H460 cells with $75 \mu \mathrm{M}$ $275 \mu \mathrm{M}$ concentration showed statistically significant $(\mathrm{p}<0.001)$ decrease in the proliferation of A549 cells. Data represents mean \pm SD of six replicates. Intergroup comparisons were made between the cell control and the treated groups. Student's t-test; $* * * \mathrm{P}<0.001$ verses control.

LDH reaction mixture $(100 \mu \mathrm{l})$ was added to each well, and after that plates were incubated for 30 minutes at room temp. The reaction was stopped by adding $10 \mu \mathrm{l}$ stop solution to each well. The red color intensity representing the LDH activity was measured at the absorbance of $450 \mathrm{~nm}$ using a microplate reader.

\subsection{Statistical analysis}

Experiments have been carried out in triplicate on at least three different time intervals and the mean of replicate values were taken. All the experimental values were expressed as mean \pm SD. Statistical analysis of the data was determined by Student's t-test and comparisons were made between the untreated control and the treated groups.

\section{Results}

3.1 Determination of $\mathrm{IC}_{50}$ of fisetin on A549 cell line

The Preliminary pilot studies were carried out with various concentrations of fisetin ranging from 10 to $400 \mu \mathrm{M}$ concentrations. Treatment of A549 cells with $50 \mu \mathrm{M}$ to 250 $\mu \mathrm{M}$ concentration for $48 \mathrm{~h}$ showed a statistically significant $((\mathrm{P}<0.001)$ decrease in proliferation of cells however the concentration above 250 to 400 and below $50 \mu \mathrm{M}$ showed no appreciable decrease in proliferation of cells when compared to $250 \mu \mathrm{M}$ concentration (data not shown). Based on MTT assay the concentration of fisetin that inhibited cell growth by $50 \%$ ( $\left.\mathrm{IC}_{50}\right)$ was determined as $190 \mu \mathrm{M}$ concentration (Figure 1a).

\subsection{Determination of $\mathrm{IC}_{50}$ of fisetin on NCI-H460 cell line}

Preliminary pilot studies were carried out with various concentrations of fisetin ranging from 10 to $300 \mu \mathrm{M}$ concentrations. Treatment of NCI-H460 with 10 to $50 \mu \mathrm{M}$ concentration for $24 \mathrm{~h}$ showed no influence on the proliferation of cells as compared to control (data not shown). Whereas concentrations between 75 to $275 \mu \mathrm{M}$ showed statistically significant $(\mathrm{P}<0.001)$ decrease in the proliferation of NCIH460 cells. Based on MTT assay the concentration of fisetin that inhibited cell growth by $50 \%\left(\mathrm{IC}_{50}\right)$ was determined as 210 $\mu \mathrm{M}$ concentration (Figure $1 \mathrm{~b}$ ).

3.3 Effect of fisetin on growth and proliferation of NCI-H460 and A549 cell line

Based on preliminary pilot studies, the $1 \mathrm{C}_{50}$ doses were further confirmed by performing XTT, BrdU, crystal violet assays (Figure 2, 3, 4).These assays were performed to confirm results obtained from MTT assay and these assays were in agreement. Based on these cell viability and proliferation assays it was observed that treatment with the specified concentrations of fisetin resulted in statistically significant decrease in cell viability, growth, survival and proliferation of A549 and NCI$\mathrm{H} 460$ cells .The $\mathrm{IC}_{50}$ doses were confirmed and used for carrying out further assays. 


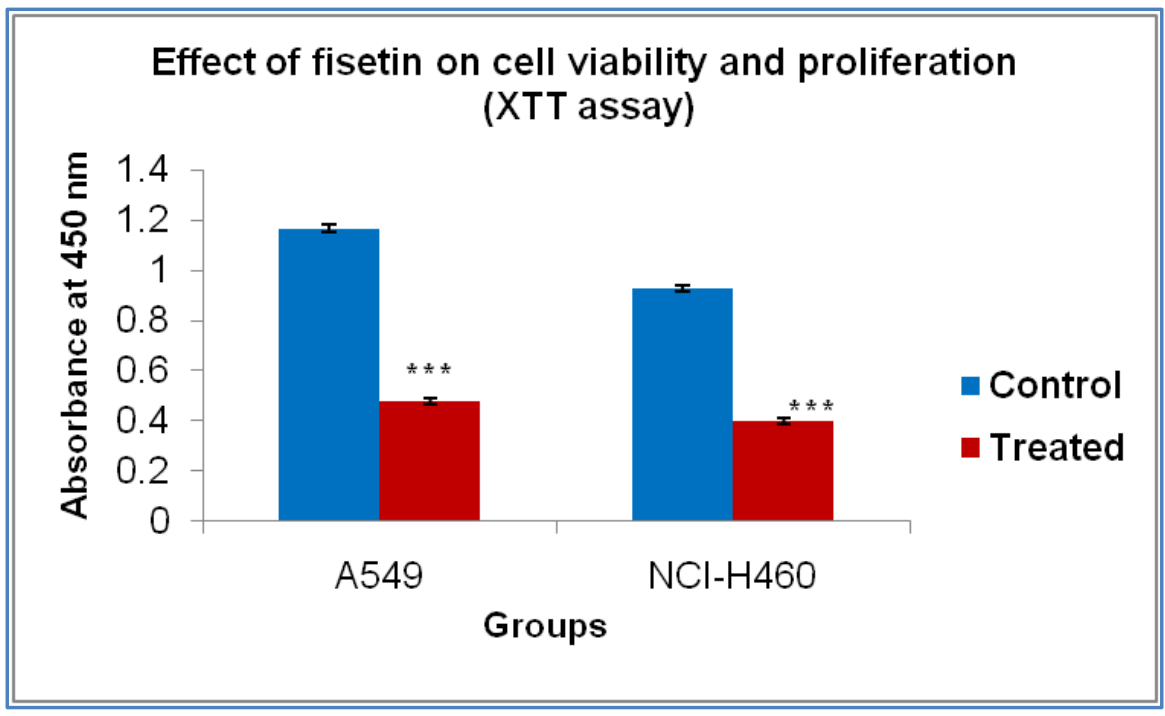

Figure 2 Effect of fisetin on proliferation of A549 and NCI-H46 cells (XTT assay) .Treatment of NCI-460 cells with fisetin resulted in a significant decrease in cell proliferation as compared with the control. Data represent mean \pm SD of six replicates. Intergroup comparisons were made between the cell control and the treated group. Student's t-test; *** $\mathrm{P}<0.001$ verses control.

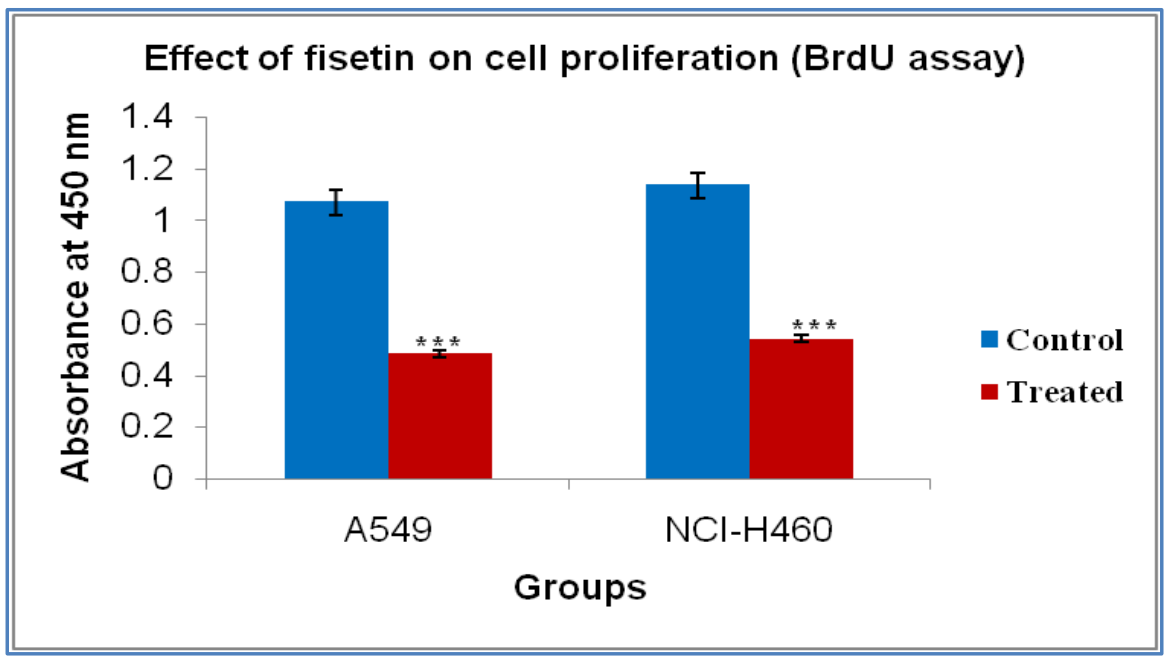

Figure 3 Effect of fisetin on proliferation of A549 and NCI-H460 cells (BrdU assay). Treatment of A549 and NCI-H460 cells with fisetin resulted in a significant decrease in cell proliferation as compared with the control. Data represent mean \pm SD of six replicates.

Intergroup comparisons were made between cell control and treated group. Student's t-test; $* * * \mathrm{P}<0.001$ verses control.

3.4 Effect of Fisetin on cell morphology-cytopathological and cytochemical analysis

\subsubsection{Crystal violet staining}

The fisetin treated A549 and NCI-H460 cells showed the presence of apoptotic bodies, cytoplasmic vacuolization, cell shrinkage, formation of stretched nuclei and nuclear fragmentation after staining the cells with crystal violet $(0.05 \%$ $\mathrm{w} / \mathrm{v}$ ) for $30 \mathrm{~min}$ (Figure $5 \mathrm{~A}$ ), however these typical features of cell death were not observed in untreated control A549 cells and NCI-H460.

\subsubsection{Hematoxylin and eosin Staining}

A549 treated cells showed decrease in cell number. The cells were smaller in size and some cells show cell shrinkage and loss of nuclei (cell death) after staining the cells with hematoxylin and eosin whereas they were not evident in the untreated control. NCI-H460 treated cells showed decrease in cell population with many cells showing loss of nuclei, and karyorrhexis was seen which, is a typical feature of apoptosis (Figure 5 B). 


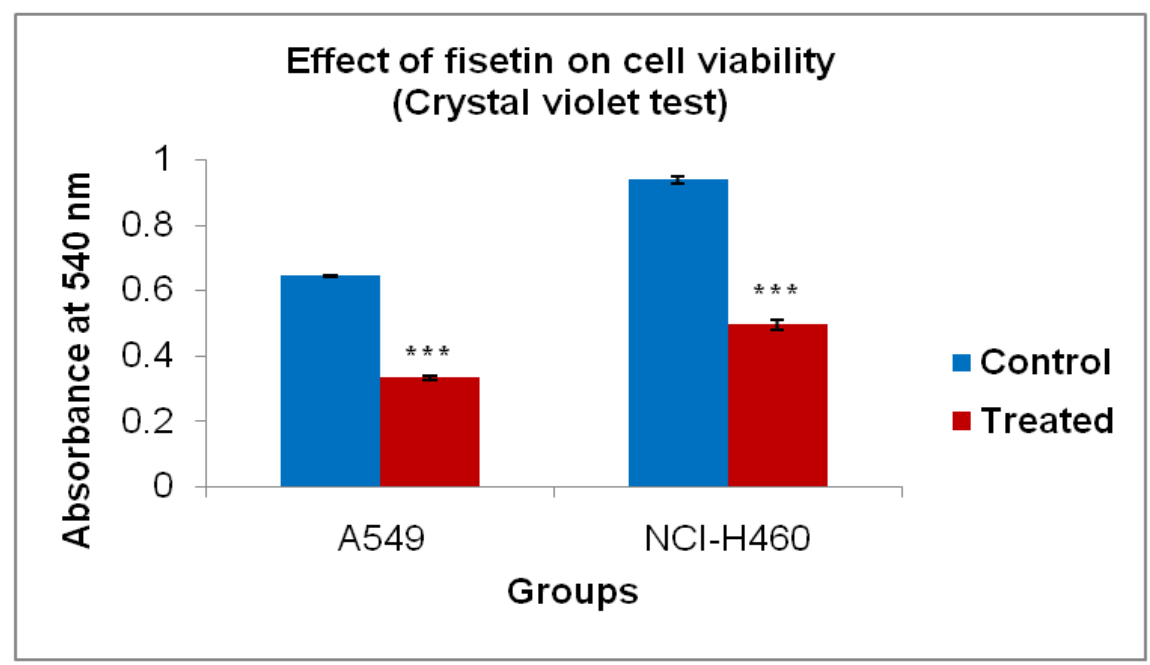

Figure 4 Effect of fisetin on proliferation of A549 and NCI-H460 cells (Crystal violet assay) -pilot studies. Treatment of A549 and NCI$\mathrm{H} 460$ cells with fisetin resulted in a significant decrease in cell proliferation as compared with control. Data represent mean $\pm \mathrm{SD}$ of six replicates. Intergroupcomparisons were made between cell control and treated groups. Student's t-test; *** $\mathrm{P}<0.001$ verses control.

3.4.3 Effect of fisetin on cloning efficiency and surviving fraction

Results revealed that A549 control cells showed a cloning efficiency of 0.82 as compared to cloning efficiency of 0.28 observed in treated cells and NCI-H460 control cells showed a cloning efficiency of 1.18 as compared to cloning efficiency of 0.34 observed in treated cells. Thus, it illustrates the significant decrease in the number of colonies and decrease in percentage of survival in fistein treated groups compared to that of untreated control (Table 1). As shown in figure fisetin treatment almost completely blocked the migration of A549 and NCI-H460 cells, and antimetastatic effect was more evident in NCI-H460 treated cells (Fig. 5 C).

\subsubsection{Effect of fisetin on release of LDH}

Results indicate that the cells treated with fisetin showed marked increase in LDH release in both A549 and NCI-H460 cells which was found to be statistically significant $(\mathrm{p}<0.001)$ as compared to untreated control (Figure 6).

\begin{abstract}
4 Discussion
Currently over $50 \%$ of anticancer drugs available in the market for therapy werederived directly or indirectly from natural source (Younes et al., 2007). Dietary factors play an important role in prevention of cancer, hence large number of dietary compounds were tested to determine their chemopreventive / antiproliferative ability in invivo / invitro model systems. A549 cells were derived from human alveolar carcinoma cell (Giard et al., 1973) and matched closely with type II alveolar cell phenotype. They share many characteristic features with human primary alveolar epithelial cell (Lieber et al., 1976). Hence they are widely used as models of lung cancer (Wang et al., 2009; Shin et al., 2009)and as human primary alveolar epithelial cells in vitro (Tian et al., 2009; Mazzarella et al., 2007). NCI-H460 cells are epithelioid cells isolated from pleural fluid of a patient with large cell carcinoma of lung. Inhibition of cell proliferation is a characteristic feature of majority of anticancer agents.
\end{abstract}

Table 1 Effect of fisetin on colony efficiency and survival fraction - colony formation in soft agar

\begin{tabular}{|lcccc|}
\hline Group & No. of Colonies & Colony Efficiency & Surviving Fraction & $\%$ Survival \\
\hline Control NCI $-\mathrm{H} 460$ & 52 & 1.04 & - & 100 \\
\hline Treated NCI $-\mathrm{H} 460$ & 11 & 0.22 & 0.211 & 21 \\
\hline Control A549 & 44 & 0.88 & - & 100 \\
\hline Treated A549 & 13 & 0.26 & 0.295 & 30 \\
\hline
\end{tabular}

Table 1 indicates the cloning efficiency and surviving fraction of the fisetin treated A549 and NCI-H460 cells and untreated control cells. A549 and NCI-H460 control cells showed a cloning efficiency of 0.82 and 1.18 compared to treated A549 and NCI-H460 cells showing cloning efficiency 0.28 and 0.34 respectively. Decrease in percentage of survival was observed in both A549 and NCI-H460 treated cells compared to untreated control cells. 


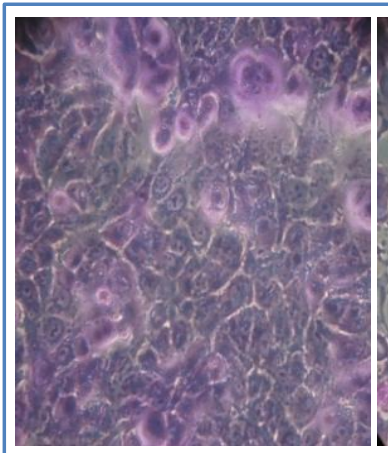

( A )

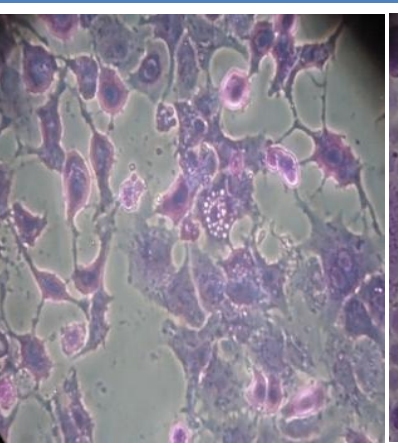

Treated A549

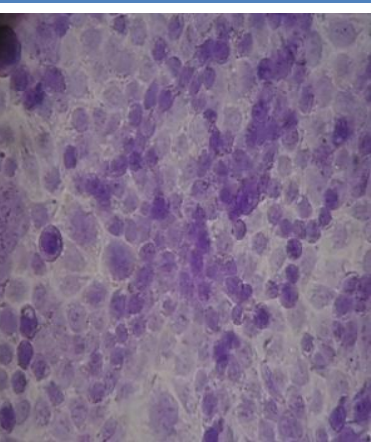

Control NCl-H460

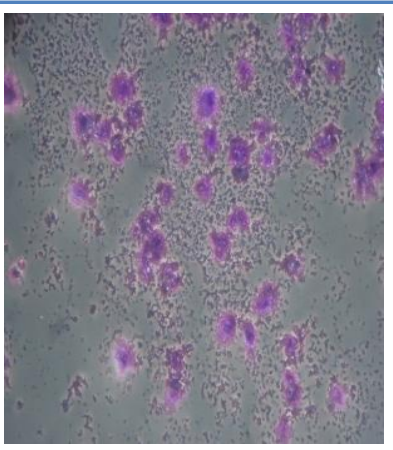

Treated NCl-H460

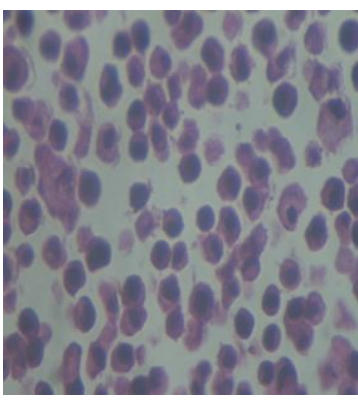

Control A549

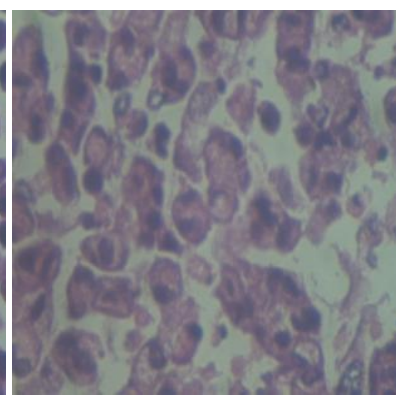

Treated A549

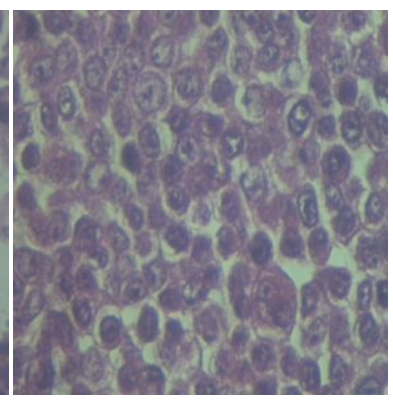

Control NCl-H460

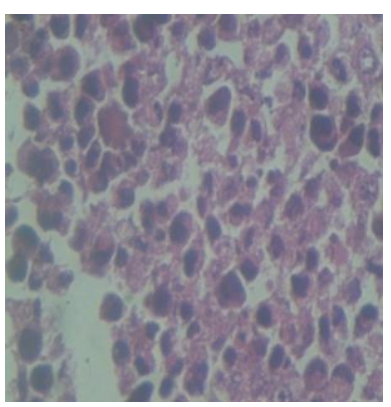

Treated NCI-H460 ( B

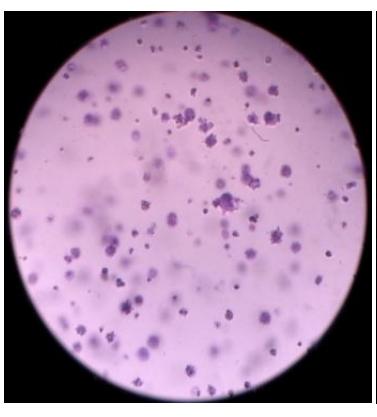

(C) Control A549

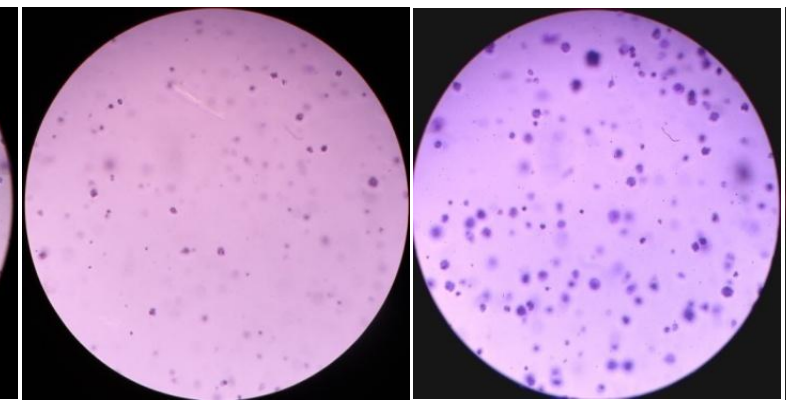

Treated A549

Control NCl-H460

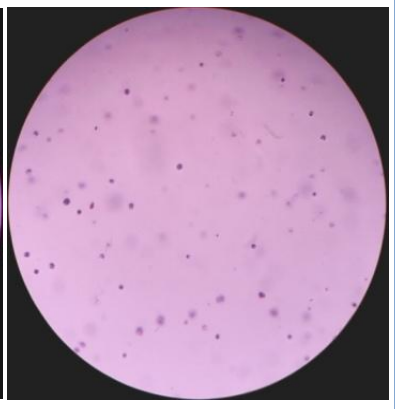

Treated NCl-H460

Figure 5 (A) Crystal violet staining revealed the presence of apoptotic bodies, cytoplasmic vacuolization, cell shrinkage, nuclear fragmentation and formation of stretched nuclei in fisetin treated A549 and NCI-H460 cells. Magnification: $\times 4 \times 10$. (B) Hematoxylin eosin staining revealed that fisetin treated A549 cells were smaller in size and some cells showed cell shrinkage and loss of nuclei (cell death) and NCI-H460 cells showe $\bar{d}$ showing loss of nuclei and karyorrhexis was seen which is a typical feature of apoptosis. However, no such features were evident in A549 and NCI-H460 control cells. Magnification: $\times 4 \times 10$. (C) Figure illustrates the effect of fisetin on colony efficiency and surviving fraction of A549 and NCI-H460 cells. Colonies formed in soft agar after 15 days were stained with $0.05 \%$ crystal violet and counted and images were captured. Magnification $\times 10$.

The flavonoid fisetin was reported to inhibit cell proliferation against several in vivo/in vitro models of carcinogenesis. The current study also showed significant inhibition of cell growth and proliferation was observed after treatment of pulmonary carcinoma cells with fisetin. In human, the Quadraplex $\left(\mathrm{G}_{4}\right)$ forming sequences in telomeric DNA and C-myc promoter regions of DNA are associated with tumorigenesis. Ligands that can help to facilitate or stabilize formation of $\mathrm{G}_{4}$ quadraplex structures and increase stabilization of $\mathrm{G}_{4}$ quadraplex can prevent tumor cell proliferation and regarded as promising candidates as anti-cancer agents (Sen gupta et al., 2013). In the recent years, particular efforts are under way to discover, design and synthesise new ligands that could help to regulate the stability of G-quadraplex structures. Fisetin is reported to act as a ligand for $\mathrm{G}_{4}$ DNA (Sengupta et al., 2013), and hence could have a tight control on the cell proliferation in A549 and NCI-H460 cells. This could be the reason for the observed inhibitory effects of fisetin on cell growth, viability and proliferation of pulmonary carcinoma cell lines. 


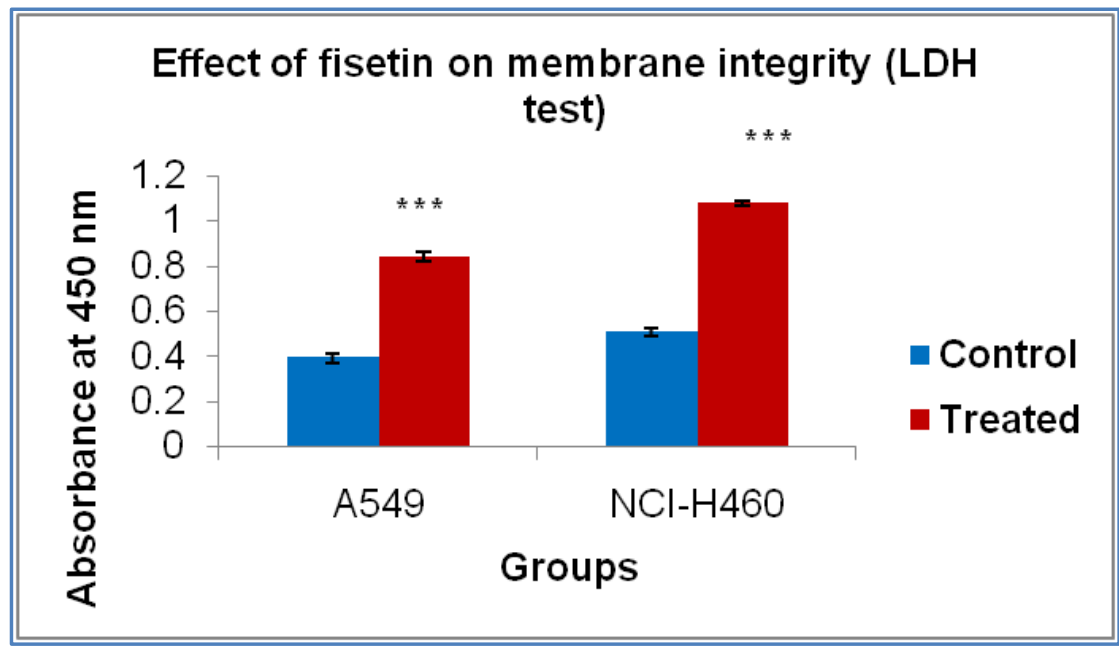

Figure 6 Effect of fisetin on LDH activity of A549 and NCI-H460 cells. Treatment of A549 and NCI-H460 cells with fisetin showed a significant increase in leakage of LDH into culture supernatant as compared to untreated control. Data represent mean $\pm \mathrm{SD}$ of six replicates. Intergroup comparisons were made between cell control and treated group. Student's t-test; ***P $<0.001$ verses control.

Neoplastic transformation takes place via a series of genetic and epigenetic changes that yield cell population with potential of proliferating independently of both external and internal signals. It is one of the hall marks of malignant transformation and most accurate in vitro indication of tumorigenicity (Shin et al., 1975). The decreased number of colonies and inhibition of anchorage independent growth of pulmonary carcinoma cells by fisetin strongly supported its potent antiproliferative effects.

Hematoxylin and eosin staining is a valuable indicator of morphological and tissue architectural changes occurring during pathological conditions. This is an indispensible test to confirm malignant transformation of normal cells or to test efficacy of compounds to prevent pathological changes in cells/tissues. Results of hematoxylin and eosin staining were in line and support observations of cell growth assays, clonogenic assay. This confirmed growth inhibitory effects of fisetin on A549 and NCI-H40 cells. LDH is a cytosolic enzyme that leaks into culture supernatant or serum during membrane damage and injury. Increased leakage of LDH into culture supernatant of cells treated with fisetin implies alteration in membrane permeability and integrity thereby results in increased leakage of enzyme out of cells.

\section{Conclusion}

The results of the current study indicate growth inhibitory, antiproliferative and cytotoxic effects of fisetin on human pulmonary carcinoma cells A-549 and NCI-H460. Although the mechanism of action remains unclear at this stage of the study, it is presumed to be due to proapoptotic effects of fisetin and its subsequent implications on multiple cell signaling pathways that mediate cell proliferation and death.

\section{Conflict of interest}

Authors would hereby like to declare that there is no conflict of interests that could possibly arise.

\section{References}

Arai Y, Watanabe S, Kimira M, Shimoi K, Mochizuki R, Kinae N (2000) Dietary intakes of flavonols, flavones and isoflavones by japanese women and the inverse correlation between quercetin intake and plasma LDL Cholesterol concentration. Journal of Nutrition 130:2243-2250.

Behrens P, Rothe M, Florin A, Wellmann A, Wernert N (2001) Invasive properties of serous human epithelial ovarian tumors are related to Ets-1, MMP-1 and MMP-9 expression. International Journal of Molecular Medicine $8: 149-54$.

Boyum A(1968) Isolation of mononuclear cells and granulocytes from human blood Isolation of mononuclear cells by one centrifugation, and of granulocytes by combining centrifugation and sedimentation at $1 \mathrm{~g}$. Scandinavian journal of clinical and laboratory investigation Supplementum 97: 7789.

Carbone DP, Felip E (2011) Adjuvant therapy in non small cell lung cancer: future treatment prospects and prospects and paradigm. Clinical lung cancer 12 : 261-271. doi: 10.1016/j.cllc.2011.06.002.

Doll R, Peto R (1981) The causes of cancer: quantitative estimates of avoidable risks of cancer in the United States today. Journal of National Cancer Institute 66 : 1191-1308. 
Fischer AH, Jacobson KA, Rose J, Zeller R (2008) Hematoxylin and eosin staining of tissue and cell sections. Cold Spring Harbor Protocols pdb. prot 4986. doi:10.1101/pdb.prot4986.

Giard DJ, Aaronson SA, Todaro GJ, Arnstein P, Kersey JH, Dosik H, Parks WP (1973) In vitro cultivation of humantumors: establishment of cell lines derived from a series of solid tumors. Journal of National Cancer Institute 51 :14171423. doi: 10.1093/jnci/51.5.1417.

Hamburger AW, Salmon SE, Kim MB, Trent JM, Soehnlen BJ, Alberts DS, Schmidt HJ (1978) Direct cloning of human ovarian carcinoma cells in agar. Cancer Research 38:34383444.

Haura EB, Zheng Z, Song L, Cantor A, Bepler G (2005) Activated epidermal growth factor receptor-Stat-3 signaling promotes tumor survival in vivo in non-small cell lung cancer. Clinical Cancer Research11 :8288-8294. DOI: 10.1158/10780432.CCR-05-0827.

Hirata H, Naito K, Yoshihiro S, Matsuyama H, Suehiro Y, Hinoda Y (2003) A single nucleotide polymorphism in the matrix metalloproteinase-1 promoter is associated with conventional renal cell carcinoma. International Journal of Cancer 106 : 372-374. DOI: 10.1002/ijc.11229.

Huntington JT, Shields JM, Der CJ, Wyatt CA, Benbow U, Slingluff CL Jr, Brinckerhoff CE (2004) Over expression of collagenase 1 (MMP-1) is mediated by the ERK pathway in invasive melanoma cells: role of BRAF mutation and fibroblast growth factor signaling. The Journal of Biological Chemistry 279 : 33168-76. doi: 10.1074/jbc.M405102200.

Khan N, Afaq F, Mukhtar H (2008) Cancer chemoprevention through dietary antioxidants: progress and promise. Antioxidants and Redox Signaling 10 : 475-510.

Lena A, Rechichi M, Salvetti A, Bartoli B, Vecchio D, Scarcelli V, Amoroso R, Benvenuti L, Gagliardi R, Gremigni V, Rossi L (2009) Drugs targeting the mitochondrial pore act as cytotoxic and cytostatic agents in temozolomide resistant glioma cells. Journal of Translational Medicine 7:13. doi: 10.1186/1479-5876-7-13.

Lieber M, Smith B, Szakal A, Nelson-Rees W, Todaro G (1976) A continuous tumor-cell line from a human lung carcinomawith properties of type II alveolar epithelial cells. International Journal of Cancer $17: 62-70$.

Liu H, Kato Y, Erzinger SA, Kiriakova GM, Qian Y, Palmicri D, Steeg PS, Price JE (2012) The role of MMP-1 in breast cancer growth and metastasis to the brain in a xenograft model. BMC Cancer 12:583. DOI: 10.1186/1471-2407-12-5.

Mazzarella G, Ferraraccio F, Prati MV, Annunziata S, Bianco A, Mezzogiorno A, Liguori G, Angelillo IF, Cazzola M (2007)
Effects of diesel exhaust particles on humanlung epithelial cells: an in vitro study. Respiratory Medicine 101 : 1155-1162. DOI: http://dx.doi.org/10.1016/j.rmed.2006.11.011.

Moon YJ, Wang X, Morris ME (2006) Dietary Flavonoids: effects on Xenobiotic and carcinogen metabolism. Toxicology In Vitro $20: 187-210$.

Mosmann T (1983) Rapid colorimetric assay for cellular growth and survival: application to proliferation and cytotoxicity assays. Journal of Immunological Methods 65 : 55-63. doi:10.1016/0022-1759(83)90303-4.

Mukohara T, Kudoh S, Yamauchi S, Kimura T, Yoshimura N, Kanazawa H, Hirata K, Wanibuchi H, Fukushima S, Inoue K, Yoshikawa J (2003) Expression of epidermal growth factor receptor (EGFR) and downstream-activated peptides in surgically excised non-small cell lung cancer (NSCLC). Lung Cancer 41 : 123-130. DOI: http://dx.doi.org/10.1016/S01695002(03)00225-3.

Kemik O, Kemik AS, Sümer A, Dulger AC, Adas M, Begenik H, Hasirci I, Yilmaz O, Purisa S, Kisli E, Tuzun S, Kotan C (2011) Levels of matrix metalloproteinase-1 and tissue inhibitors of metalloproteinase- 1 in gastric cancer. World Journal of Gastroenterology 17 :2109-12. doi: 10.3748/wjg.v17.i16.2109.

Seki Y, Suzuki N, Imaizumi M, Iwamoto T, Usami N, Ueda Y, Hamaguchi M (2004) STAT3 and MAPK in human lung cancer tissues and suppression of oncogenic growth by JAB and dominant negative STAT3. International Journal of Oncology 24 : 931-934. DOI: 10.3892/ijo.24.4.931.

Sengupta B, Pahari B, Blackmon L, Sengupta PK (2013) Prospect of bioflavonoid fisetin as a quadruplex DNA ligand: a biophysical approach. PLoS One 8 : e65383. doi: 10.1371/journal.pone.0065383.

Shin S, Cha HJ, Lee EM, Lee SJ, Seo SK, Jin HO, Park IC, Jin YW, An S (2009) Alteration of miRNA profiles by ionizingradiation in A549 human non-small cell lung cancer cells. International Journal of Oncology $35: 81-86$.

Shin SI, Freedman VH, Risser R, Pollack R (1975) Tumorigenicity of virus-transformed cells in nude mice is correlated specifically with anchorage independent growth in vitro. Proceedings of the National Academy of Sciences USA 72:4435-4439.

Song, L Rawal B, Nemeth JA, Haura EB (2011) JAK1 activates STAT3 activity in non-small-cell lung cancer cells and IL-6 neutralizing antibodies can suppress JAK1-STAT3 signaling. Molecular Cancer Therapeutics 10 : 481-494. DOI: 10.1158/1535-7163.

Tian D, Zhu M, Li J, Ma Y, Wu R (2009) Cigarette smoke extract induces activation of beta-catenin/TCF signaling 


\begin{tabular}{|c|c|}
\hline S38 & Gazala et al \\
\hline $\begin{array}{l}\text { through inhibiting GSK3beta in human alveolar epithelial cell } \\
\text { line. Toxicology Letter } 187 \quad \text { : 58-62. doi: } \\
\text { 10.1016/j.toxlet.2009.02.002.. }\end{array}$ & $\begin{array}{l}\text { nicotine and a tobacco carcinogen modulates the phenotype of } \\
\text { normal human airway epithelial cells. Journal of Clinical } \\
\text { Investigation } 111: 81-90 \text {. DOI: } 10.1172 / \text { JCI16147. }\end{array}$ \\
\hline $\begin{array}{l}\text { Wang Y, Yang H, Liu H, Huang J, Song X (2009) Effect of } \\
\text { staurosporine on the mobility and invasiveness of lung } \\
\text { adenocarcinoma A549 cells: an in vitro study. BMC Cancer } \\
\text { 9:174. DOI: } 10.1186 / 1471-2407-9-174 \text {. }\end{array}$ & $\begin{array}{l}\text { Younes RN, Varella AD, Suffredini IB (2007) Suffredini } \\
\text { Discovery of new antitumoral and antibacterial drugs from } \\
\text { Brazilian plant extracts using high throughput screening. } \\
\text { Clinics 62(6): 763-768. http://dx.doi.org/10.1590/S1807- } \\
59322007000600017 \text {. }\end{array}$ \\
\hline
\end{tabular}

West KA, Brognard J, Clark AS, Linnoila IR, Yang X, Swain SM, Harris C, Belinsky S, (2003) Rapid Akt activation by 